\title{
Dietary fish oil modulates the effect of dimethylhydrazine-induced colon cancer in rats
}

\author{
By G.E. Rasmy, ${ }^{, 1}$ W.K.B. Khalil, ${ }^{2}$ S.A. Moharib, ${ }^{1}$ A.A. Kawkab, ${ }^{3}$ and E.W. Jwanny ${ }^{1}$ \\ (1) Biochemistry Department, National Research Centre, 12622 Dokki, Cairo, EGYPT. \\ (2) Cell Biology Department, National Research Center, 12622 Dokki, Cairo, EGYPT. \\ ${ }^{(3)}$ Department of pathology- Faculty of Vet. Med. Cairo Univ., EGYPT.
}

( ${ }^{*}$ Corresponding author: gefahmy @ gmail.com)

\section{RESUMEN}

Efecto del aceite de pescado de la dieta en cáncer de colon inducido por dimetilhidrazina en ratas.

Este estudio fue realizado para examinar la eficacia de la suplementación de aceite de pescado en la carcinogénesis de colon en ratas wistar machos. Para la inducción del cáncer de colon, las ratas fueron tratadas semanalmente con una inyección subcutánea de 1,2-dimethyl hydrazine $(\mathrm{DMH})$ a una dosis de $20 \mathrm{mg} / \mathrm{kg}$ de peso durante cinco semana. A continuación, algunas ratas tomaron aceite de pescado durante 4 semanas, o durante 17 semanas (grupo DMH-FO17). Las ratas restantes continuaron sin ningún tipo de suplementación durante las mismas 4 semanas (grupo DMH4), o 17 semanas (grupo DMH17). Otros dos grupos de ratas no recibieron $\mathrm{DMH}$ y un grupo consumió aceite de pescado (grupo FO17) y el otro solamente una dieta normal y es considerado como el grupo control (grupo CN). Al final del experimento, las ratas fueron sacrificadas; y a continuación fueron evaluadas mediante análisis bioquímico y biología molecular así como examen histopatológico. El resultado mostro un incremento en los niveles de lactato deshidrogenasa (LDH), malondialdehido (MDS) y fosfatasa alcalina (ALP) en ratas DMH en comparación con el control. Los cambios inducidos en el hígado y el colon por DMH fueron significativamente mejorados con la suplementación de aceite de pescado en el grupo DMH-FO17. El análisis molecular revelo que el tratamiento con $\mathrm{DMH}$ indujo alteraciones de la expresión de los genes p53, p27 y p21 e incremento el perfil de bandas de DNA relacionadas con el cáncer, mientras que los grupos FO17 Y DMH-FO17 mostraron mejores resultados. El examen histológico del grupo $\mathrm{DMH} 17$ revelo adenocarcinoma de colon y algunas lesiones en tejidos de hígado de rata. La mejora en el perfil histológico fue notable en el hígado y colon del grupo DMH-FO17. En conclusión, los presente resultados demuestran el efecto anti-carcinogénico del aceite de arenque contra la carcinogénesis de colon inducida por DMH en ratas. El efecto inhibidor de FO fue debido a la modulación de parámetros bioquímicos elevados, daño a DNA y lesiones histopatológicas causadas por $\mathrm{DMH}$.

PALABRAS CLAVE: Aceite de pescado - Cáncer colorrectal - DMH - Expresión génica - Ratas.

\section{SUMMARY}

Dietary fish oil modulates the effect of dimethylhydrazine-induced colon cancer in rats.

This study was conducted to examine the efficacy of fish oil supplementation in male wistar rat colon carcinogenesis.
In order to induce colon cancer, the rats were given a weekly subcutaneous injection of 1,2-Dimethylhydrazine $(\mathrm{DMH})$ at a dose of $20 \mathrm{mg} / \mathrm{kg} \mathrm{b.w}$. for five weeks. Afterwards, some of the rats ingested fish oil for either 4 weeks (DMH-FO4 group), or 17 weeks (DMH-FO17 group). The remaining rats continued without any supplementation for the same 4 weeks (DMH4 group), or 17 weeks (DMH17 group). Another two groups of rats did not receive the $\mathrm{DMH}$ and were given fish oil (FO17 group) or a normal diet only and considered as the control group (CN group). At the end of the experiment, the rats were sacrificed; and were subsequently subjected to biochemical and molecular biological analyses as well as histopathological examinations. The results showed increased levels of lactate dehydrogenase (LDH), malondialdehyde (MDA) and alkaline phoshatase (ALP) activities in the DMH rats compared to the control. The liver and colonic changes that were induced by $\mathrm{DMH}$ were significantly improved through fish oil supplementation in the DMH-FO17 group. The molecular analysis revealed that $\mathrm{DMH}$ treatment induced the expression alterations of genes p53, p27 and p21 and increased DNA band patterns related to cancer, while both FO17 and DMH-FO17 groups showed much better results. A histopathological examination of the $\mathrm{DMH} 17$ group revealed colon adenocarcinoma and several lesions in rat liver tissues. An improvement in the histopathological picture was seen in the livers and colons of groups $\mathrm{DMH}$ FO17. In conclusion, the present results demonstrated the anti-carciongenic effect of herring fish oil against $\mathrm{DMH}$ induced colon carcinogenesis in rats. The inhibitory effect of FO was due to the modulation of elevated biochemical parameters, DNA damage, gene expression and histopathological lesions caused by $\mathrm{DMH}$.

KEY-WORDS: Colorectal cancer - DMH - Fish oil Gene expression - Rats.

\section{INTRODUCTION}

Among the factors that contribute to the appearance of cancer, diet plays a fundamental role. Fats are the main component related to the increase in the incidence of cancerous diseases, particularly breast, prostate and colorectal cancer. Colon cancer is one of the leading causes of death in both men and women in Western countries (Parker et al., 1995; and Jemal et al., 2003) and it became the number six leading cause of cancer deaths in Egypt (WHO report, 2006). Several 
approaches to lowering the incidence of colon cancer have included attempts at dietary prevention and chemoprevention (Giovannucci and Willett; 1994; Rao et al., 2001, Levin et al., 2008, Dougherty et al., 2009 and Wong, 2010).

The relationship between nutrition and cancer is complex; where nutrition constitutes an important aspect of the life of cancer patients. Wynder et al., 1969 , suggested that dietary factors in general, and dietary fat in particular, play a role in the etiology of colon cancer. Since then, several epidemiological and case-control studies provided evidence for an association between the intake of dietary fat and total calories and an increased risk for the development of colon cancer (Giovannucci and Willett, 1994, Dougherty et al., 2009). However, assumptions that eating a diet with a high polyunsaturated fat content (rich in n-3 fatty acids) may decrease the risk of colorectal cancer have been hypothesized in relation to fish and fish oil (Tavani et al., 2003). Diets rich in n-3 fatty acids (marine oils) reduce the risk of chemically induced colon carcinogenesis compared with diets high in n-6 fatty acids and/or saturated fatty acids. This suggests that the composition of ingested dietary fatty acids is more critical to colon cancer risk than is the total amount of fat (Chang et al., 1998 and Sarotra et al., 2010). In addition, laboratory animal model assays have indicated that the influence of type and amount of dietary fat is exerted foremost during the post-initiation phase of carcinogenesis (Reddy et al., 1991). In general, the overall evidence from studies with laboratory animals is consistent with the epidemiological data. The beneficial effects of $n-3$ fatty acids are postulated to be associated with the known anti-inflammatory actions of $n-3$ FAs; however, the specific mechanism(s) of action has not been defined. The results of numerous studies (Narayanan et al., 2001; Stoll, 2002; Cheng et al., 2003; Granados et al., 2006) illustrated a lower morbidity and therefore improved quality of life after using $n-3$ polyunsaturated fatty acids (PUFAs). In general, an increased $n-3$ fatty acid consumption ameliorates or decreases the risk of a variety of diseases. N-3 fatty acids have definite roles in cardiovascular disease, cognitive development and learning, visual function, the immune-inflammatory response, pregnancy outcomes, neurological degeneration, and cancer (Seo et al., 2005, jwanny et al., 2009).

$\mathrm{DMH}$ (1,2-Dimethyl hydrazine) was used as a potent and complete carcinogen for the colon, since it has been reliably used to induce the initiation and promotion steps of colon carcinogenesis in rodents either after a single dose (Ward, 1974) or after five doses over 5 successive weeks (jwanny et al., 2009).

The mechanisms by which n-3 PUFAs decrease colon tumor formation has not been fully elucidated. The examination of genes up- or down- regulated at various stages of tumor development via the monitoring of gene expression relationships will help to determine the biological processes ultimately responsible for the protective effects of n-3 PUFAs.
The development of malignant tumors is associated with excessive cell proliferation, deregulation of cellular differentiation, insufficient apoptosis and genomic instability (Kornberg et al., 2005). p53, a protein encoded by the TSG p53 functions as a guardian of the genome facilitating cell cycle arrest, differentiation and apoptosis thereby decreasing the accumulation of mutant cell populations (Levine, 1997, Thapa et al., 2010), p21 and p27, cyclin dependent kinase inhibitors, are important regulators of cell cycle progression (Watson et al., 2008).

Therefore, the present study was designed to investigate the therapeutic effect of fish oil (obtained from byproducts of the fish canning industry) on chemically induced colon cancer in rats using a colon specific carcinogen; i.e. $\mathrm{DMH}$. This was carried out by assessing biochemical and histopathological alterations, evaluating DNA damage and analyzing the expression of p53, p21 and p27 genes in relation to fish oil as biomonitor chemoprevention.

\section{MATERIALS AND METHODS}

\subsection{Materials}

The human colon cancer cell line (HCT116) was kindly donated from the National Cancer Institute, Cairo, Egypt. It was placed on 96 multi-well plates for $24 \mathrm{~h}$ before treatment with the compound(s) to allow for the attachment of the cells to the walls of the plates.

The carcinogenic agent, 1,2 dimethylhydrazine dihydrochloride $99+\%(\mathrm{DMH})$ was obtained from Sigma-Aldrich, Steinheim, Germany.

Herring Fish oil was obtained from the byproducts of fish canning industries, Egypt. The fish oil was extracted and purified according to Folch et al. (1957). Fish oil was ingested every 2 days at a dose of $0.3 \%$ wt/wt diet (Jwanny et al., 2004).

\subsection{Methods}

The fatty acid composition of fish oil was identified by GLC after methylation according to the method of Lepage and Roy (1986) and Jwanny et al. (2001). Cytotoxicity tests of the purified fish oil were assayed using the sulforhodamine B (SRB) assay according to the method described by Skehan et al., 1990.

\subsection{Experimental Animals}

Fifty-six male Wistar strain rats weighing 75-100g were obtained from the Animal House Colony, National Research Center, Cairo, Egypt. The animals were kept individually in wire bottomed cages at room temperature $\left(25 \pm 2^{\circ} \mathrm{C}\right)$ under a 12-hour dark-light cycle. They were maintained on a standard laboratory diet and water ad libitum. The animals were allowed to adjust to their new conditions for one week before commencing the experiment and then they were distributed into seven 
cages (8 rats/each). All animals received humane treatment, in compliance with the guidelines of the Animal Care and Use Committee of the National Research Center, Egypt. At the end of the experimental period, blood samples were drawn from each rat separately using capillary tubes, and centrifuged at $4000 \mathrm{xg}$ for $10 \mathrm{~min}$. Separated sera were used for different biochemical analyses. Liver and colon were removed and used for molecular biology analyses and histological tests.

\subsection{Experimental design}

The Institutional Animal Ethics Committee approved the study. The experimental design is illustrated in Fig. 1. For the induction of colon cancer, 40 rats were subcutaneously injected with the carcinogenic material (DMH), once a week, for five successive weeks at a dose of $20 \mathrm{mg} / \mathrm{kg} \mathrm{b.w}$. according to Cheng et al., 2003 and Jwanny et al., 2009. After the 5 weeks of ingestion, this point was considered as time zero of the experiment and the animals were then divided into 5 groups ( 8 rats/ each) as follows: one group (8 animals) were sacrificed for analysis (group DMH0); two groups of $\mathrm{DMH}$-rats continued for either 4 or 17 weeks without FO supplementation (groups DMH4 \& DMH17, respectively); the last $2 \mathrm{DMH}$-rat groups were treated with fish oil for either four weeks (group DMH-FO4), or for 17 weeks (group DMH-FO17).

Another two groups of rats (8/each) were subcutaneously injected with saline instead of the $\mathrm{DMH}$, with the same dose for five weeks and one of them was sacrificed for analysis (control group, $\mathrm{CN}$ ). The last group received the same dose of fish oil for the same 17 weeks (group FO17).

\subsection{Biochemical analyses}

Blood sera from the rats of all experimental groups were obtained from the whole blood by allowing it to coagulate for $20 \mathrm{~min}$ at $4^{\circ} \mathrm{C}$ then centrifuging at $2000 \mathrm{~g}$ for $15 \mathrm{~min}$ and immediately subjecting it to biochemical analysis. The distal colon and whole liver were quickly removed, rinsed in ice-cold saline, blotted on filter paper, and kept in formalin $10 \%$ until histological examination.

\section{Determination of malondialdehyde (MDA)}

The concentration of malondialdehyde (MDA) was measured with a thiobarbituric acid test according to the method described by Ohkawa et al. (1979) using a Biodignostic kit, Egypt. The results were expressed as nmol thiobarbituric acid reactive substances $/ \mathrm{ml}$. $\mathrm{nmol} / \mathrm{ml}$.

\section{Determination of lactate dehydrogenase ( $L D H)$}

LDH activity (U/ L) was estimated according to the method of Buhl and Jackson (1978) using a Stanbio Laboratory kit, USA.

\section{Determination of Alkaline Phoshatase (ALP)}

Determination of ALP (IU/L) was carried out according to the DGKC indications, Germany (1972).

\section{Determination of Aspartate aminotransferase $(A S T)$ and Alanine aminotransferase (ALT)}

AST and ALT activities were measured using kits of QCA, Spain, according to the method of Reitman and Frankel, (1957). AST and ALT activities were expressed as U/L.

\subsection{RAPD-PCR analysis}

The use of molecular markers has provided important advances in the characterization and genetic variation in many species, including yeasts and mammals (Gallego et al., 2005; Horng et al.,

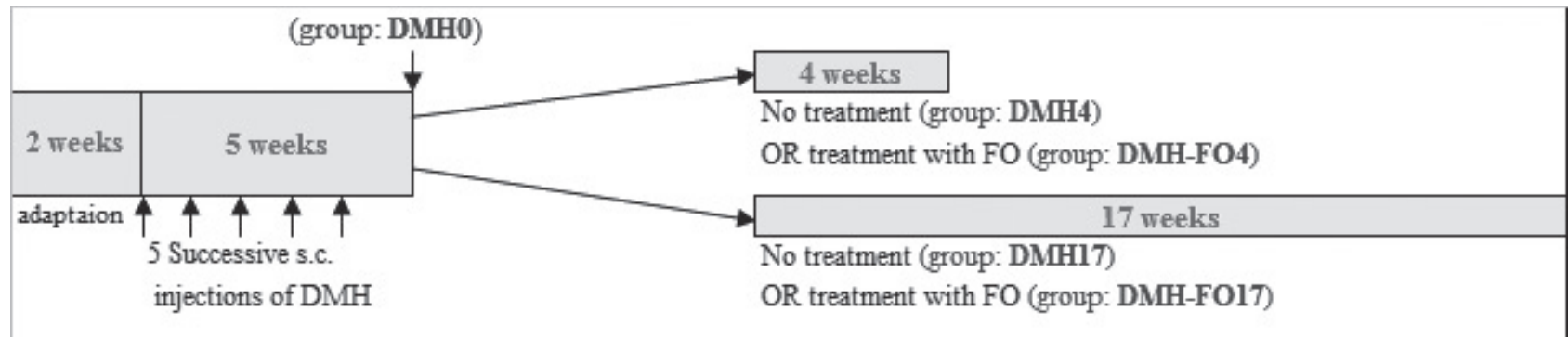

(Control group: $\mathrm{CN}$ )


2004). PCR-based techniques, such as RAPDs, have previously allowed for the discrimination as well as estimation of genetic variation attributed to genotoxic elements such as $\mathrm{DMH}$.

The genomic DNA was isolated from the colon and liver of rats using phenol/chloroform extraction and the ethanol precipitation method with minor modifications. Purity of the DNA was evaluated by absorbances at 230, 260, and $280 \mathrm{~nm}$ (Aquardo et al., 1992). When impurities were present (pure DNA has a ratio of $A 260 / A 230=1.7-2.2)$, the DNA sample was passed through the commercial UltraClean Soil kit until satisfactory purity was reached.

To generate RAPD profiles from rat DNA, 10-mer primer kits $A$ and $D$ from the Operon Technologies (USA), were used. DNA amplification reactions were performed under conditions reported by Khalil et al. (2007, 2008). PCR amplification was conducted in $20 \mu \mathrm{l}$ reaction volume containing $100 \mathrm{ng}$ genomic DNA; $100 \mu \mathrm{M}$ dNTPs; $40 \mathrm{nM}$ primer (Operon, Almeda, CA, USA); 2.5 units of Taq DNA polymearse and $5 \mu$ promega 10X Taq DNA polymearse buffer. The reactions were carried out in a Thermocycler (Applied Biosystems 9700) programmed with an initial denaturation of $5 \mathrm{~min}$ at $94^{\circ} \mathrm{C}$, followed by 45 cycles of $0.5 \mathrm{~min}$ at $94^{\circ} \mathrm{C}, 1$ min at $36^{\circ} \mathrm{C}$ and $2 \mathrm{~min}$ at $72^{\circ} \mathrm{C}$ and finally, one cycle at $72^{\circ} \mathrm{C}$ for $5 \mathrm{~min}$. The PCR product was analyzed by electrophoresing $15 \mu$ l of the amplified mixture on agarose gel. The Gel-Pro Analyzer (Media Cybernetics) was used to document ethidium bromide DNA gels.

\subsection{Semi-quantitative Reverse Transcription-PCR}

\section{RNA extraction and Synthesize} of First-strand cDNA

Immediately after killing the animals, colon tissues from the rats of each experimental group were kept in liquid nitrogen until used for gene expression analysis. Stored colon tissue samples were used to extract the total RNA. Total RNA was isolated from $100 \mathrm{mg}$ of tissue by the standard TRIzol extraction method (Invitrogen, UK) and recovered in $100 \mu \mathrm{l}$ molecular biology grade water. In order to remove any possible genomic DNA contamination, the total RNA samples were pre-treated using DNA-free ${ }^{\mathrm{TM}}$ DNase treatment and removal reagents kit (Ambion, Austin, TX, USA) following the manufacturer's protocol. The RNA concentration was determined by spectrophotometric absorption at $260 \mathrm{~nm}$.

To synthesize the first-strand cDNA, $5 \mu \mathrm{g}$ of the complete Poly $(A)+$ RNA isolated from rat samples was reverse transcribed into CDNA at a total volume of $20 \mu \mathrm{l}$ using $1 \mu \mathrm{l}$ oligo (poly(deoxythymidine)18) primer. The composition of the reaction mixture consisted of $50 \mathrm{mM} \mathrm{MgCl}$, 10x reverse transcription (RT) buffer (50 mM KCl; 10 mM Tris-HCl; pH 8.3), $200 \mathrm{U} / \mu \mathrm{l}$ reverse transcriptase (RNase $\mathrm{H}$ free), $10 \mathrm{mM}$ of each $\mathrm{dNTP}$, and $50 \mu \mathrm{M}$ of oligo(dT) primer. The RT reaction was carried out at $25^{\circ} \mathrm{C}$ for $10 \mathrm{~min}$, followed by $1 \mathrm{~h}$ at $42^{\circ} \mathrm{C}$, and finished with a denaturation step at $99^{\circ} \mathrm{C}$ for 5 min. Afterwards, the reaction tubes containing RT preparations were flash-cooled in an ice chamber until being used for DNA amplification through polymerase chain reaction (PCR).

\section{RT-PCR assay}

The first strands of cDNA from different colon tissue samples were used as templates for the semi-quantitative RT-PCR with a pair of specific primers in a $25-\mu$ l reaction volume. The sequences of specific primer and product sizes are listed in Table 1. $\beta$-Actin was used as a housekeeping gene for normalizing mRNA levels of the target genes. The reaction mixture for $R T-P C R$ consisted of $10 \mathrm{mM}$ dNTP's, 50 mM MgCl2, 10x PCR buffer (50 mM KCl; $20 \mathrm{mM}$ Tris-HCl; $\mathrm{pH} 8.3), 1 \mathrm{U} / \mu \mathrm{l}$ taq polymerase and autoclaved water. The PCR cycling parameters of the studied genes (p53, p21 and p27) were performed as the PCR condition summarized in Table 1. The PCR products were then loaded onto $2.0 \%$ agarose gel, with PCR products derived from the $\beta$-actin of

Table 1

Primers and PCR thermocycling parameters

\begin{tabular}{|c|c|c|c|}
\hline Primer & Sequence (5'-3') & PCR conditions & RT-PCR (bp) \\
\hline p53 & $\begin{array}{l}\text { CGCAAAAGAAGAAGCCACTA } \\
\text { TCCACTCTGGGCATCCTT }\end{array}$ & $\begin{array}{c}25 \text { cycles: } 94^{\circ} \mathrm{C}, 30 \mathrm{~s} ; 65^{\circ} \mathrm{C}, 30 \mathrm{~s} ; \\
68^{\circ} \mathrm{C}, 1 \mathrm{~min} \\
\text { Final extension: } 68^{\circ} \mathrm{C}, 2 \mathrm{~min}\end{array}$ & 118 \\
\hline p21 & $\begin{array}{l}\text { ACCTCTCAGGGCCGAAAAC } \\
\text { TAGGGCTTCCTCTTGGAGAA }\end{array}$ & $\begin{array}{c}25 \text { cycles: } 94^{\circ} \mathrm{C}, 30 \mathrm{~s} ; 65^{\circ} \mathrm{C}, 30 \mathrm{~s} ; \\
68^{\circ} \mathrm{C}, 1 \mathrm{~min} \\
\text { Final extension: } 68^{\circ} \mathrm{C}, 2 \mathrm{~min}\end{array}$ & 88 \\
\hline p27 & $\begin{array}{l}\text { CAGAGGACACACACTTGGTAGA } \\
\text { TCTTTTGTTTTGAGGAGAGGAA }\end{array}$ & $\begin{array}{c}35 \text { cycles: } 93^{\circ} \mathrm{C}, 30 \mathrm{~s} ; 56^{\circ} \mathrm{C}, 45 \mathrm{~s} ; \\
74^{\circ} \mathrm{C}, 45 \mathrm{~s} \\
\text { Final extension: } 74^{\circ} \mathrm{C}, 10 \mathrm{~min}\end{array}$ & 124 \\
\hline$\beta$-Actin & $\begin{array}{l}\text { GTGGGCCGCTCTAGGCACCAA } \\
\text { CTCTTTGATGTCACGCACGATTTC }\end{array}$ & $\begin{array}{c}25 \text { cycles: } 94^{\circ} \mathrm{C}, 30 \mathrm{~s} ; 65^{\circ} \mathrm{C}, 30 \mathrm{~s} ; \\
68^{\circ} \mathrm{C}, 1 \mathrm{~min} \\
\text { Final extension: } 68^{\circ} \mathrm{C}, 2 \mathrm{~min}\end{array}$ & 540 \\
\hline
\end{tabular}


the different rat samples. Each reaction of the RTPCR was repeated with ten rats, generating new cDNA products at least ten times per group.

\subsection{Histopathological examination}

Tissue specimens from liver and colon were fixed in neutral buffered formalin $10 \%$ and processed by the conventional method, embedded in paraffin, sectioned at 4-5 um and stained by Haematoxylin and Eosin (Bancroft et al., 1996)

\subsection{Statistical Analysis}

Data from the biochemical analysis was statistically analyzed according to the method of Fisher, 1970. Data from the molecular biology studies were analyzed using the General Liner Models (GLM) procedure of Statistical Analysis System (SAS, 1982) followed by the Scheffé-test to assess significant differences among groups. All statements of significance were based on a probability of $\mathrm{P}<0.05$.

\section{RESULTS}

\subsection{Fatty acid analysis of fish oil}

Fatty acid methyl esters were subjected to GLC analysis. Data presented in Table 2 revealed the presence of $36.2 \%$ (wt/wt) as n-3 PUFAs, of which $21.6 \%$ was eicosapentaenoic acid (EPA) and $11.0 \%$ was docosahexaenoic acid (DHA) and $4.5 \%$ (wt/wt) was $n-6$ PUFAs. The $n-6 / n-3$ ratio $=0.12$

\subsection{Cytotoxic activity}

The cytotoxic activity of fish oil in the human colon cancer cell line (HCT116) revealed that the dose value of fish oil exposure required to reduce survival in the cell lines to $50 \%\left(\mathrm{IC}_{50}\right)$ was a very small dose $(1.4 \mu \mathrm{g} / \mathrm{ml})$.
Table 2

Fatty acid composition of herring fish oil methyl esters

\begin{tabular}{lr}
\hline Total Saturated FAs & $\mathbf{2 6 . 2}$ \\
\hline $\mathrm{C}_{12: 0}$ & 0.0 \\
$\mathrm{C}_{14: 0}$ & 7.8 \\
$\mathrm{C}_{16: 0}$ & 18.4 \\
$\mathrm{C}_{20: 0}$ & 0.0 \\
\hline Total Monounsaturated FAs & $\mathbf{2 4 . 8}$ \\
\hline $\mathrm{C}_{16: 1}$ & 1.1 \\
$\mathrm{C}_{18: 1}$ & 11.5 \\
$\mathrm{C}_{20: 1}$ & 12.2 \\
\hline Total Polyunsaturated FAs & $\mathbf{4 0 . 7}$ \\
\hline $\mathrm{C}_{18: 22-6}$ & 0.0 \\
$\mathrm{C}_{18: 3 n-3}$ & 3.6 \\
$\mathrm{C}_{20: 4 n-6}$ & 4.5 \\
$\mathrm{C}_{20: 5 n-3}(\mathrm{EPA})$ & 21.6 \\
$\mathrm{C}_{22: 0 n-3}(\mathrm{DHA})$ & 11.0 \\
\hline
\end{tabular}

\subsection{Biochemical parameters}

The Results in Table 3 show that the DMHO group exhibited significantly higher values in MDA, LDH levels, ALP and AST activities compared to the control $(+92.18 \%,+469.92,+165.6 \%$, and $143.8 \%$, respectively, $P<0.001$ for all).

Compared to DMH0, Both MDA levels and ALP activity changed insignificantly after 4 weeks whether the rats were treated (DMH-FO4) or untreated (DMH4). However, the DMH-FO17 group exhibited a significant decrease both in MDA levels and ALP activity compared to DMHO (-28.43\%, $P<0.01,-54, P<0.001$, respectively).

Table 3

Effects of DMH and/or dietary fish oil on the measured biochemical parameters in experimental animals

\begin{tabular}{|c|c|c|c|c|c|c|c|}
\hline & $\mathrm{CN}$ & DMHO & DMH4 & DMH-FO4 & DMH17 & DMH-F017 & F017 \\
\hline $\begin{array}{c}\mathrm{MDA} \\
(\mathrm{nmol} / \mathrm{ml})\end{array}$ & $7.33 \pm 0.27$ & $14.08^{\text {aa }} \pm 0.73$ & $13.80 \pm 0.87$ & $12.69 \pm 0.44$ & $12.73 \pm 0.23$ & $10.08^{c} \pm 0.67$ & $9.65 \pm 0.51$ \\
\hline $\begin{array}{l}\mathrm{LDH} \\
(\mathrm{U} / \mathrm{L})\end{array}$ & $171.16 \pm 3.76$ & $975.47^{\mathrm{aa}} \pm 40.02$ & $766.36 \pm 32.08$ & $750.02 \pm 60.41$ & $717.97 \pm 34.75$ & $558.23^{c c} \pm 24.83$ & $315.32 \pm 22.45$ \\
\hline $\begin{array}{l}\text { ALP } \\
(I U / L)\end{array}$ & $145.57 \pm 2.41$ & $386.58^{\mathrm{aa}} \pm 10.15$ & $364.85 \pm 9.75$ & $380.41 \pm 32.44$ & $249.55 \pm 5.50$ & $177.82^{c c} \pm 12.62$ & $195.22 \pm 12.77$ \\
\hline $\begin{array}{l}\text { AST } \\
(\mathrm{U} / \mathrm{L})\end{array}$ & $24.61 \pm 0.89$ & $60.00^{\mathrm{aa}} \pm 3.54$ & $100.29 \pm 6.89$ & $71.25^{\mathrm{bb}} \pm 4.27$ & $300.00 \pm 25.07$ & $80.50^{c c} \pm 10.05$ & $50.86 \pm 5.82$ \\
\hline $\begin{array}{l}\mathrm{ALT} \\
(\mathrm{U} / \mathrm{L})\end{array}$ & $34.72 \pm 0.90$ & $45.00 \pm 3.87$ & $53.63 \pm 3.60$ & $42.75^{b} \pm 2.56$ & $98.25 \pm 10.79$ & $136.50^{\circ c} \pm 4.27$ & $38.00 \pm 5.29$ \\
\hline
\end{tabular}

N.B. significance values are given in superscript above each number if found as follows; ${ }^{a}(p<0.05)$ and ${ }^{\text {aa }}(p<0.01)$ when comparing DMHO vs CN , ${ }^{b}(p<0.05)$ and ${ }^{b b}(p<0.01)$ when comparing DMH-FO4 vs DMH4 and ${ }^{c}(p<0.05)$ and ${ }^{c c}(p<0.01)$ when comparing DMH-FO17 vs DMH17. 
When compared to DMH0, LDH levels exhibited mildly lower levels both in $\mathrm{DMH} 4$ and $\mathrm{DMH}-\mathrm{FO} 4$ groups (-21.44\%, $P<0.05,-23.11 \%, P<0.05$, respectively) after 4 weeks. Also, DMH-FO17 exhibited highly significantly lower levels of LDH (-42.77\%, $P<0.001$ ). On comparing DMH-FO 17 with $\mathrm{DMH} 17$, a significantly lower level $(-22.25 \%$, $\mathrm{p}<0.01$ ) was also observAST activity increased dramatically in all DMH groups at 4 and 17 weeks ( $+143.82 \%,+67.14 \%,+400.0 \%$, respectively, $P<0.001$ for all). FO groups inhibited this marked elevation starting from week 4 (DMH-FO4, +18.75\%, $P>0.005)$ to week 17 (DMH-FO17, 34.17\%, $P>0.05$, compared to DMH0. Also at week 17 (DMH-FO17) ALT activity decreased dramatically by $73.17 \%$ $(P<0.001)$ compared to $\mathrm{DMH} 17$.
After the 17 weeks, ALT activity increased significantly in $\mathrm{DMH} 17$ compared to $\mathrm{DMHO}(+118.33 \%$, $P<0.001)$. This dramatic increase was inhibited by $-62.85 \%(p<0.01)$ with the FO treatment in DMH-FO17.

\subsection{RAPD fingerprinting pattern}

To evaluate the genetic variability among the cancer drug treated rat genomes and their control, 5 primers (10-mer random primers) were used to determine DNA fingerprinting. All of the primers used gave positive and detectable bands (Fig. 2). These random primers amplified a total of 151 different bands, ranging from 96 to 924 base pairs.

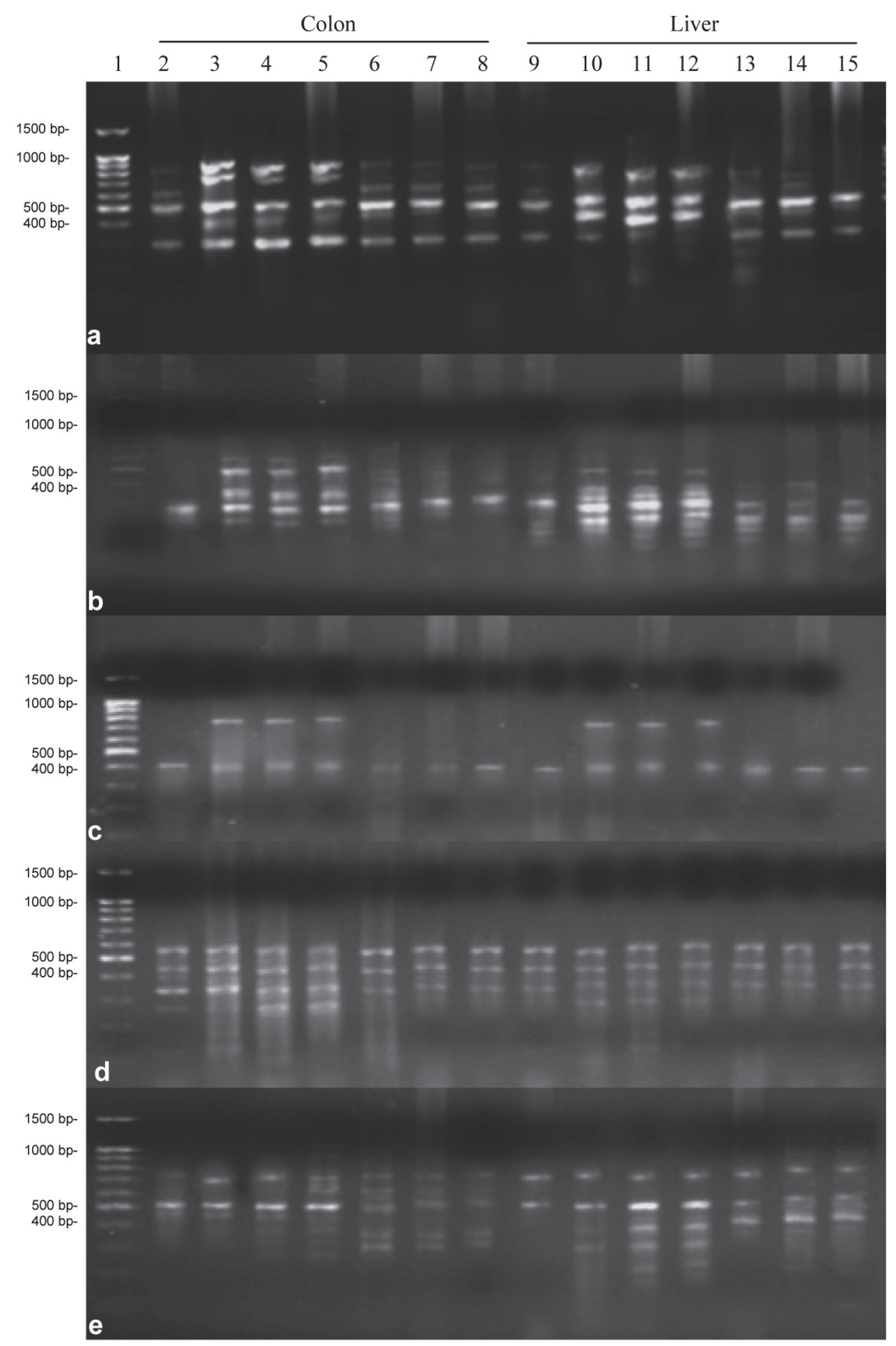

Figure 2

Comparison of RAPD fingerprinting profiles of different rat genomic DNA. a, b, c, $d$ and e agarose gels represent PCR products with primers

D01, D03, D04, D06 and A06, respectively. Lane 1 represents DNA marker. Lanes 2 and 9 represent control group. Lanes 3 and 10 represent rats of DMHO group. Lanes 4 and 11 represent rats of DMH4 group. Lanes 5 and 12 represent rats of DMH17 group. Lanes 6 and 13 represent rats of group DMH-FO4. Lanes 7 and 14 represent rats of group DMH-FO17. Lanes 8 and 15 represent rats of group FO17. 
Over all samples, the number of RAPD bands generated per primer varied between 20 and 56 bands, with an average of $46.2 \pm 2.8$ bands per primer. Nearly the same results were obtained when the PCR assay was performed for each sample within each group (7 rats).

The bands obtained from the colon and liver samples in the protected groups with fish oil (DMH-FO4 and DMH-FO17) were similar when compared with untreated rats $(\mathrm{CN})$. Where, of the scorable bands, $83(54.9 \%)$ were similar "monomorphic" for the untreated control, protected and fish oil samples. The bands were similar for the colon and liver samples in the untreated control and the short and long duration protection with fish oil as well as the fish oil samples (Fig. 2). However, the DNA of the colon and liver samples induced with cancer drugs revealed the appearance of $68(45 \%)$ new bands (polymorphic), which did not appear in the samples of the other groups (Fig. 2). These new bands, which included an increase in the band number, could be considered as "genus diagnostic" markers which are attributed to the $\mathrm{DMH}$ treatment. In addition, the appearance of these new bands was more evident in the colon than in the liver as shown in the primers D01 and D06. However, primers A06 and D03 revealed an increase in the number of these new bands in liver samples more than in colon samples (Fig. 2).

\subsection{Semi-quantitative RT-PCR}

Reverse transcription polymerase chain reaction was conducted to verify the expression of the P53, P21 and P27 genes which are related to cancer progression in the colon tissues of male rats exposed to $\mathrm{DMH}$ and fish oil for several time intervals using gene expression analysis (Table 1).

The results of the present study revealed that the expression level of the p53 gene was significantly higher in colon tissues treated with DMHO than untreated tissues (Fig. 3). The same trend was seen in the animals treated with $\mathrm{DMH}$ and survived one (DMH4) or three (DMH17) months after cancer induction. However, the expression level of the p53 gene in the groups treated with fish oil (FO) alone or fish oil for one (DMH-FO4) or three months (DMH-FO17) after cancer induction was similar to the control group (Fig. 3).

A

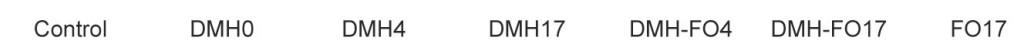

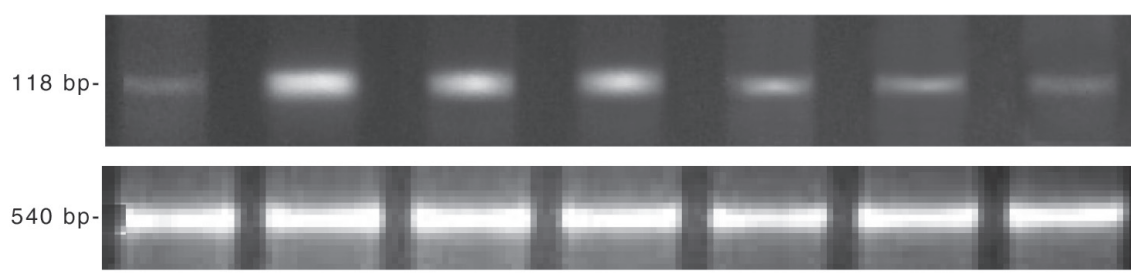

P53

$\beta$-actin

B

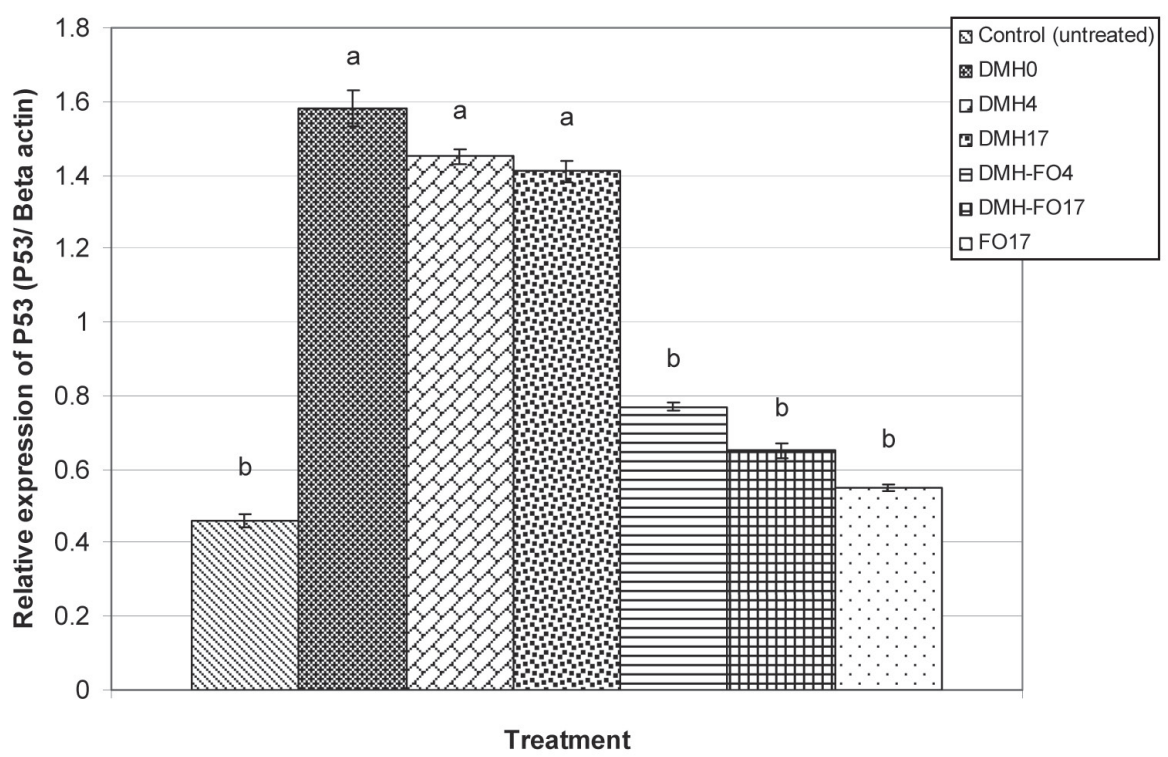

Figure 3

Semi-quantitative RT-PCR confirmation of the P53 gene in colon tissues of different rat groups. a,b values within each column mean superscripts with different letters are significantly different $(P \leq 0.05)$. 
The expression profile of p27 and p21 genes was significantly higher in colon tissues exposed to $\mathrm{DMH}$ for 5 weeks (DMH0) than in untreated tissues (Figs. 4 and 5). Similar results were found in the animals treated with $\mathrm{DMH}$ and survived one (DMH4) or three months (DMH17) after cancer induction. However, the expression level of p27 and p21 genes in the groups treated with fish oil alone or fish oil for three months (DMH-FO17) after cancer induction was similar to the control group (Figs. 4 and 5). At the same time, the expression level of p27 and p21 genes in the groups treated with fish oil for one month after cancer induction was higher than those in the control group (Figs. 4 and 5).

\subsection{Histopathological parameters}

Liver

The examined rat liver from the group treated with $(\mathrm{DMH})$ for 4 weeks revealed hydropic degeneration of hepatocytes (Fig. 6a), a portal edema associated with leucocytic cells infiltration in the portal triad. Focal hepatic hemorrhage (Fig. 6b) was also observed in some examined sections. Severe histopathological changes were noticed in the liver at 17 weeks post treatment with (DMH17), those changes described as focal areas of hepatic necrosis (Fig. 6c) with pyknosis of hepatocytes nuclei (Fig. 6d), fibrosis in the portal triads (Figs. 6d $\& 6 e)$ as well as necrosis of the epithelial lining bile duct (Fig. 6e). However, improvement in the histopathological picture was noticed in the liver of rats treated with $\mathrm{FO}(\mathrm{DMH}-\mathrm{FO})$. The liver of rats from this group showed no histopathological changes except slight hydropic degeneration of some hepatocytes (Fig. 6f). No changes were observed in the liver of rats from the (FO) group and the negative control group (Fig. 6g).

\section{Colon}

Histopathologically, the colon from the group treated with $(\mathrm{DMH})$ for 4 weeks showed marked necrosis of the intestinal villi and some intestinal glands (Fig. 7a) in the lamina propria. Moreover, some examined sections revealed an activation of mucous secreting glands, periglandular connective tissue proliferation associated with mononuclear

A $\begin{array}{lllllll}\text { Control } & \text { DMHO } & \text { DMH4 } & \text { DMH17 } & \text { DMH-FO4 } & \text { DMH-FO17 } & \text { FO17 }\end{array}$

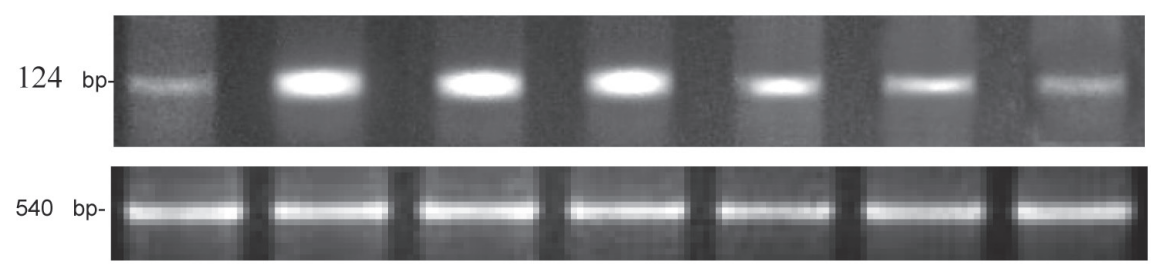

\section{B}

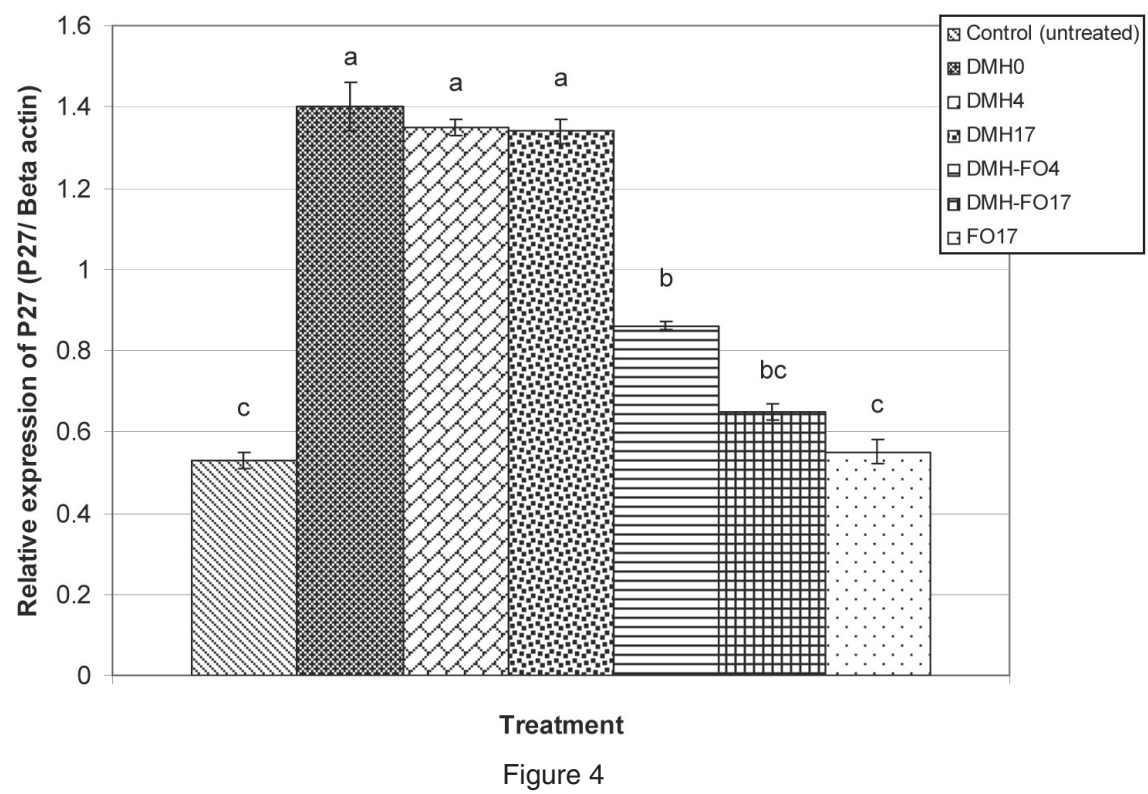

Semi-quantitative RT-PCR confirmation of the P27 gene in colon tissues of different rat groups. a,b,c values within each column mean superscripts with different letters are significantly different $(P \leq 0.05)$. 


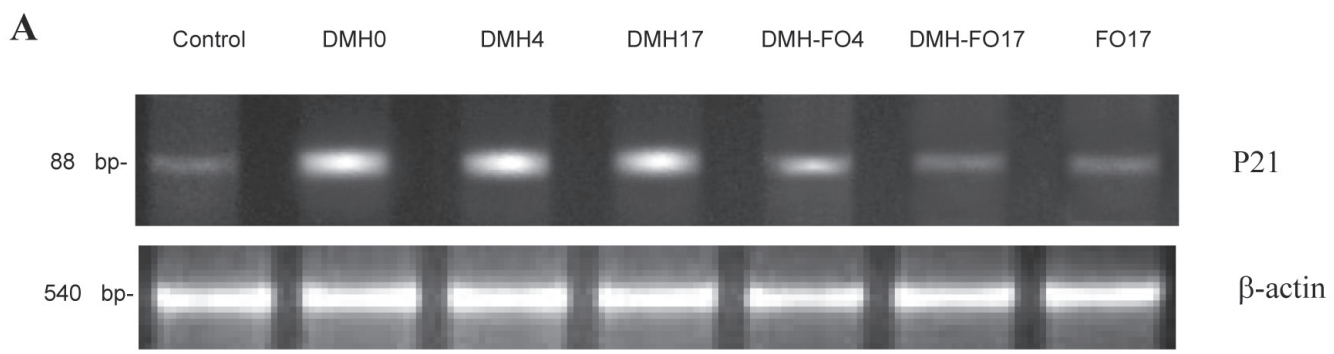

B

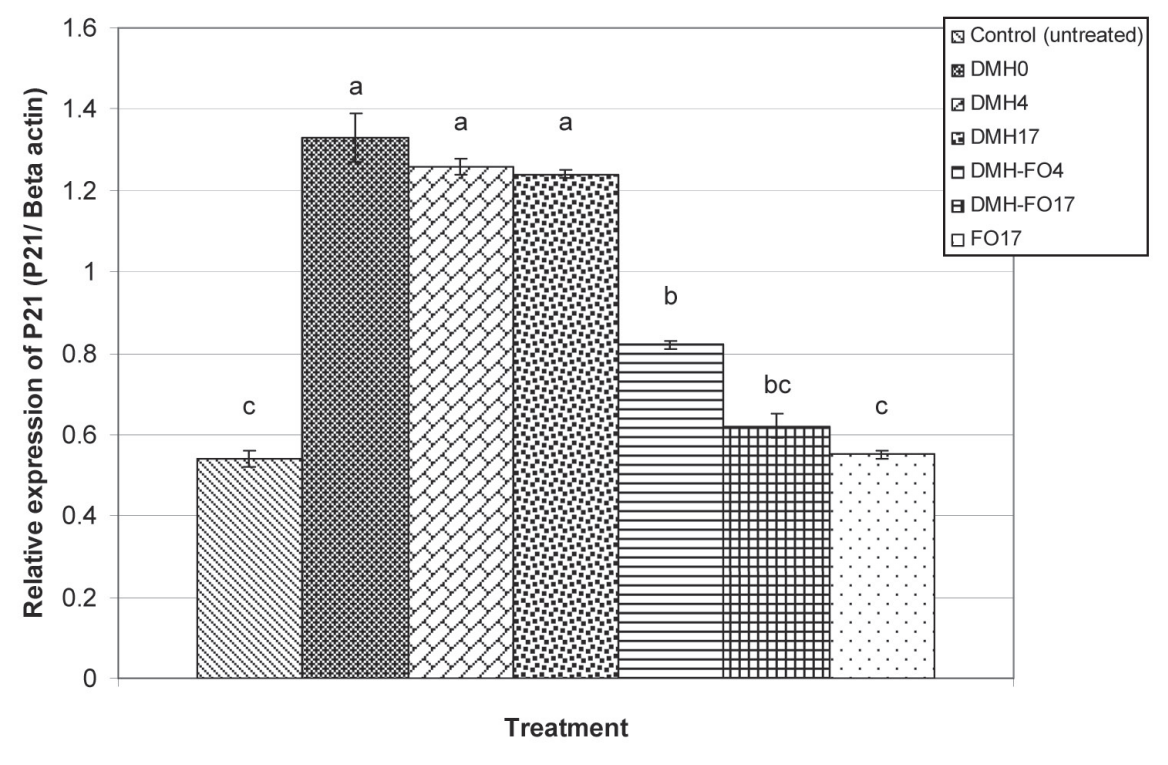

Figure 5

Semi-quantitative RT-PCR confirmation of the P21 gene in colon tissues of different rat groups. a,b,c values within each column mean superscripts with different letters are significantly different $(P \leq 0.05)$.

leucocytic cell infiltration. Meanwhile, the colon of the group treated with (DMH) for 17 weeks showed adenocarcinoma characterized by destruction of the glandular basement membrane (Fig. 7b), hyperchromasia of nuclei as well as mitotic figures. Marked necrosis in the intestinal mucosa, connective tissue proliferatioin and massive inflammatory cell infiltration (Fig. 7c) were also recorded in all examined sections. On the other hand, colon sections of rats treated with FO alone and those treated with both $\mathrm{DMH}-\mathrm{FO}$ showed apparently normal structures (Fig. $7 d$ and 7e). No histopathological altrations were noticed in the colon of rats from the negative control group (Figs.7f and 7g).

\section{DISCUSSION}

Colorectal cancer is a leading cause of cancerrelated deaths and its prevention is of great importance throughout the world (Chang et al., 2008). The etiology of colorectal cancer is very complex, and both genetic and environmental factors are thought to be involved in this process. Among environmental factors, dietary habits play an important role. Many epidemiological studies have demonstrated a positive relationship between dietary fat intake and colorectal cancer (Riboli and Norat, 2003, Rao et al., 2001 and Wu et al., 2004). Many experimental and epidemiological studies suggest that not only the amount of fat intake but also the composition of ingested dietary fatty acids are crucial factors for colon carcinogenesis. (Fujise et al., 2007, Sarotra et al., 2010 and Sala-Vila et al., 2010).

N-6 PUFA as well as saturated fatty acids (SFA) promoted colon carcinogenesis, particularly in postinitiation or promotional phases or both (Reddy, 2000 and Wu et al., 2004 and Sarotra et al., 2010). On the other hand, diets rich in n-3 PUFA and n-9 monounsaturated fatty acid (MUFA) have been reported to reduce colon tumorigenesis in both the initiation and postinitiation phases (Bartoli et al., 2000; Rao et al., 2001 and Wu et al., 2004, Chapkin et al., 2008, van Beelen et al., 2009 and Sarotra et al., 2010), supporting epidemiological reports showing that an n-3 PUFA-rich diet suppressed the risk of colon cancer in humans (Byers, 1996 and Caygill and Hill, 1995).

In this study, the beneficial effects obtained upon ingesting herring fish oil were probably due to the presence of large amounts of $n-3$, with an 

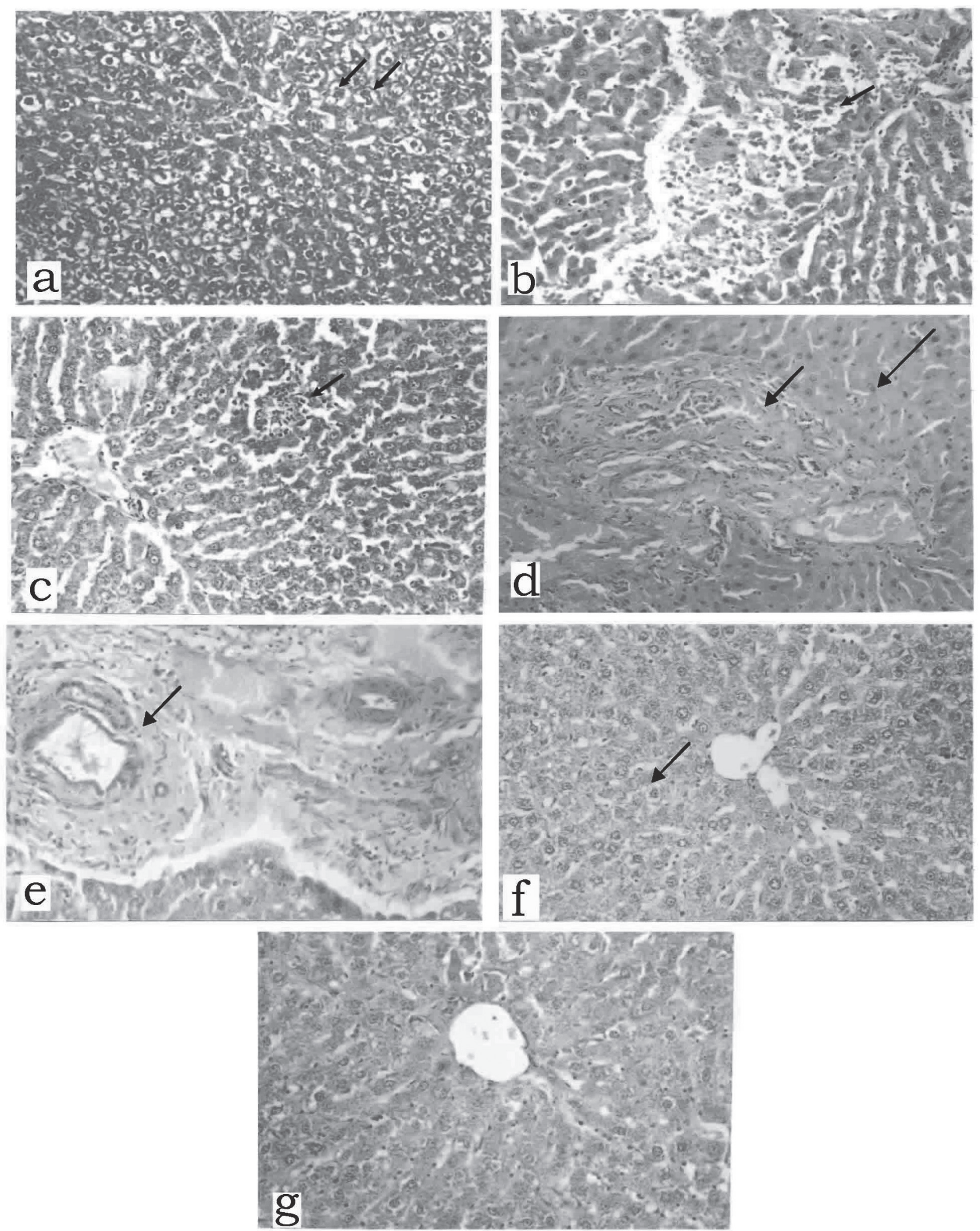

Figure 6

Photomicrographs of liver from male rats treated with $\mathrm{DMH}$ and/or fish oil: (a) Liver from rats of group DMH0 showing hydropic degeneration of hepatocytes (arrows), (H \& E X 200). (b) Liver from rats of group DMH0 showing focal hepatic hemorrhage dispersed the hepatocytes from each other (arrow), (H \& E X 200). (c) Liver from rats of group DMH17 showing focal area of hepatic necrosis associated with leucocytic cell infiltration (arrow), (H \& E X 200). (d) Liver from rats of group DMH17 showing fibrosis in the portal triad (small arrow) and pyknosis of hepatocytic nuclei (large arrow)(H \& E X 200). (e) Liver from rats of group

DMH17 showing fibrosis in the portal triad and necrosis of epithelial lining bile duct (arrow), (H \& E X 200).

(f) Liver from rats of group DMH-FO17 showing slight hydropic degeneration of hepatocytes (arrow), (H \& E X 200).

(g) Liver from rats of group CN showing no histopathological changes (H \& E X 200). 

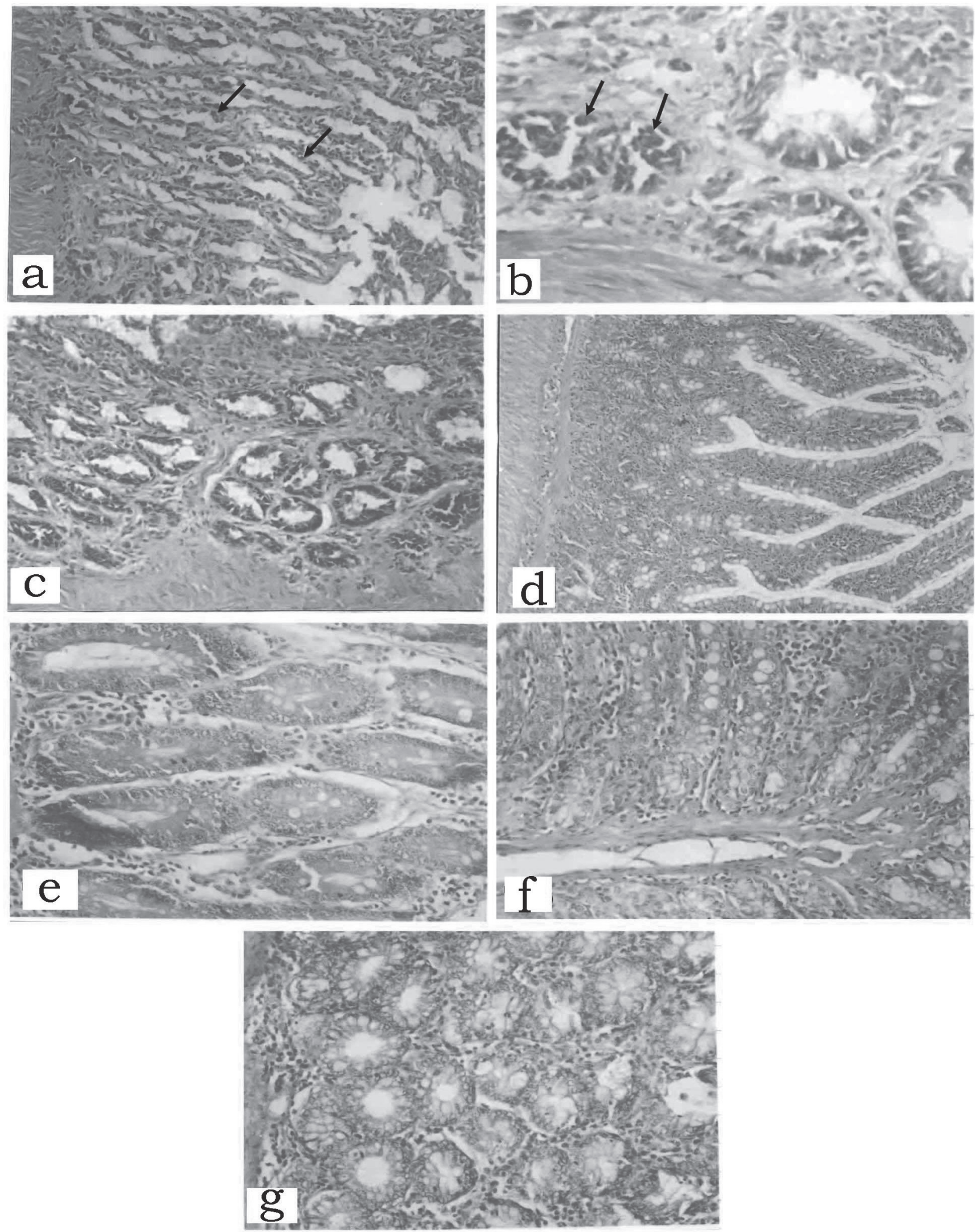

Figure 7

Photomicrographs of colons from male rats treated with $\mathrm{DMH}$ and/or fish oil: (a) Colon from rats of group DMHO showing marked necrosis of the intestinal villi and intestinal glands (arrows), (H \& E X 200). (b) Colon from rats of group DMH17 showing adenocarcinoma. Notice proliferating cells with distruction of glandular basement membrane (arrows), (H \& E X 400).

(c) Colonfrom rats of group DMH17 showing periglandular connective tissue proliferation associated with little leucocytic cell infiltration (arrow), (H \& E X 200). (d) Colon from rats of group FO17 showing apparently normal histological structure (H \& E X 100). (e) Colon from rats of group DMH-FO17 showing no histopathological changes (H \& E X 200). (f) Colon from rats of CN showing no histopathological changes (H \& E X 200). (g) Colon from rats of control group showing normal glands (H \& E X 200). 
excellent $n-6 / n-3$ ratio which equals 0.12 . This is because if $(n-3)$ fatty acids are available, they will be used as a substrate by COX 2. (Rose \& Connolly, 2000 and Yang et al., 2002). The result is that if n-3 FAs are included in the diet, they are incorporated into cell membranes and then less of the inflammation-producing and growth-promoting prostaglandin E2 will be produced in normal and in tumor tissues (Hardman, 2004).

Investigators have previously reported that the co-incubation of various cancer cell lines with $n-3$ fatty acids ( $n-3 F A$ ) leads to a reduction in cell number which is time and dose dependent (Jordan and Stein, 2001; Lee and Hwang, 2002; Sharma et al., 2005). In this study, fish oil rich in n-3 PUFAs suppressed the growth of the colon tumor cell line (HCT-116) at a very small dose $(1.4 \mu \mathrm{g} / \mathrm{ml})$. It was previously suggested that these in vitro inhibitory effects may be attributed to the inhibition of prostanoid synthesis from arachidonic acid (Boudreau et al., 2001), or by suppressing the activity of peroxisome proliferator-activated receptors (PPAR) (Lee and Hwang, 2002) but not due to the induction of apoptosis (Sala-Vila et al., 2010).

$\mathrm{DMH}$, an alkylating agent, when injected subcutaneously, is transported to the liver where it undergoes dehydrogenation and is converted to an active carbonium ion through several processes, to be excreted in the bile, where it mediates its carcinogenic activities in the mucosa while passing through the digestive tract. In this study $\mathrm{DMH}$ was used as a potent and complete carcinogen for colon, since it has been reliably used to induce the initiation and promotion steps of colon carcinogenesis in rodents even after a single dose (Ward, 1974). Metabolic activation of DMH to highly reactive electrophiles (methyldiazonium ion) occurs normally in the liver and colon. However, the main target organ of $\mathrm{DMH}$ is the large intestine (Brady et al., 1998, Choudhary and Hansen, 1998). Sasaki et al. (2000) reported that $\mathrm{DMH}$ is genotoxic in the stomach and the colon after i.p. treatment, where it is able to induce DNA damage in these target organs (Nalini et al., 2004). In the present study, $\mathrm{DMH}$ was able to induce DNA damage and alterations in the expression of the P53, P21 and P27 genes as well as histopathological lesions in the tissues of rats after 5 weeks of s.c. injections (DMH0) as evidence of the formation of cancer in these tissues. Moreover, the biochemical parameters determined in the present study supported these findings in which alkaline phosphatase (ALP), Malondialdehyde (MDA) and lactate dehydrogenase $(\mathrm{LDH})$ appeared to be increased significantly. In addition, the results showed that at 4 or 17 weeks after cancer induction by $\mathrm{DMH}$ without fish oil supplements (DMH4 and DMH17) the DNA damage, alterations in the expressions of the tested genes and the histopathological lesions, still remained in the tissues. These results are in agreement with previous findings (Cheng et al., 2003, Anilakumar et al., 2004, Kamaleeswari et al., 2006, Jwanny et al., 2009; Moreira et al., 2009 and Hill et al., 2010).
Previous studies have indicated a capacity for dietary fish oil to modulate cell turnover in the colonic mucosa of normal rats (Pell et al., 1994) and humans (Anti et al., 1994). It has been reported that prolonged feeding with fish oil increases apoptosis in the colonic mucosa during the promotion stage of chemical carcinogenesis (Chang et al., 1997 and Chang et al., 1998) but the stage of carcinogenesis and the mechanism by which dietary lipids interact with the induction of neoplasia are largely unknown. Latham et al. (1999) showed that dietary fish oil may suppress the induction of neoplastic lesions by modulating the balance of mitosis and apoptosis in the crypt at a critical stage as it responds to the cytotoxic and genotoxic effects of $\mathrm{DMH}$.

Our results revealed that after the $\mathrm{FO}$ supplementation, the DMH-FO group had significantly lower levels in most measured biochemical parameters, lower DNA damage, lower up-regulation of the expressions of the tested genes i.e. P53, P21 and P27 as well as fewer histopathological lesions compared to both $\mathrm{DMHO}$ and DMH17. During cancer development, cell turnover, differentiation and apoptosis are impaired. Many factors influence tumor induction and growth in colon cancer, including a range of cytokines and growth factors, along with genotoxic and oxidative stress. N-3 PUFAs are able to influence colon carcinogenesis by altering enzyme expression and/ or activity and, therefore, the concentrations of end products, or by modulating the levels of available precursors for biosynthetic pathways. Latham et al. (1999) suggested that n-3 PUFA can protect against the carcinogenic effects of $\mathrm{DMH}$ by mediating changes in the balance proliferation and cell death. Seo et al. (2005) illustrated that the positive effects of $n-3$ fatty acids on health related to 1) inhibition or modulation of eicosanoid pathways, which leads to the alteration of inflammatory responses and related protein expression and activity; 2) modulation of molecules or enzymes associated with various signaling pathways involving normal and pathologic cell function; 3) incorporation of n-3 fatty acids into membrane phospholipids; and 4) direct effects on DNA damage and gene expression. Because the above pathways are highly interactive, the biological potentials of $n-3$ fatty acids on health and disease must be due to multiple coordinated mechanisms.

\section{CONCLUSION}

In conclusion, the dietary administration of fish oil, obtained from byproducts of the fish canning industry, significantly suppressed the development of $\mathrm{DMH}$ induced rat colorectal cancer, through reduced serum levels of MDA, LDH and ALP activity, inhibit DNA damage, down-regulation of cancer related genes and histopathological lesions, thus modulating cell proliferation in the intestine. Further investigations are now needed to determine 
the long-term anticarcinogenic effects of $\mathrm{FO}$ on tumor development and to clarify the underlying mechanisms of action.

\section{REFERENCES}

Anilakumar KR, Khanum F, Sudarshanakrishna KR, Santhanam K. 2004. Effect of amaranth leaves on dimethylhydrazine-induced changes in multicomponent antioxidant system of rat liver. Indian J. Exp. Biol. 42 , $595-600$

Anti M, Armelao F, Marra G, Percesepe A, Bartoli GM, Palozza P, Parrella P, Canetta C, Gentiloni N, De Vitis I, et al. 1994. Effects of different doses of fish oil on rectal cell proliferation in patients with sporadic colonic adenomas. Gastroenterology 107, 17091718.

Aquardo CF, Noom WA, Begun SJ. 1992. RFLP analysis using heterologous probes. In: Hoelzel, A.R., (ed.), Molecular genetic analysis of populations, a practical approach. IRL press, Oxford., pp. 115-157.

Bancroft JD, Stevens A, Turner DR. 1996. Theory and practice of histological techniques. 4th Ed. New York, Churchill, Livingstone.

Bartoli R, Femandes-Banares F, Navarro E, Castella E, Mane J, Alvarez M, Pastor C, Cabre E, Gassull MA. 2000. Effect of olive oil on early and late events of colon carcinogenesis in rats: modulation of arachidonic acid metabolism and local prostaglandin E2 synthesis. Gut. 46, 191-199

Boudreau MD, Sohn KH, Rhee SH, Lee SW, Hunt JD Hwang DH. 2001. Suppression of Tumor Cell Growth Both in Nude Mice and in Culture by n-3 Polyunsaturated Fatty Acids: Mediation through Cyclooxygenase-independent Pathways. Cancer Research 61, 1386-1391.

Brady JF, Li D, Ishizaki H, Yang CS. 1998. Effect of diallyl sulfide on rat liver microsomal nitrosamine metabolism and other monooxygenase activities. Cancer Research 48, 3937-3940.

Buhl SN, Jackson KY. 1978. Optimal conditions and comparison of lactate dehydrogenase catalysis of the lactate-to-pyruvate and pyruvate-to-lactate reactions in human serum at 25, 30, and 37 degrees C. Clin. Chem. 24, 828-31.

Byers T. 1996. Nutrition and cancer among American Indians and Alaska Natives. Cancer 78, 1612-1616.

Caygill CP, Hill MJ. 1995. Fish, n-3 fatty acids and human colorectal and breast cancer mortality. Eur. J. Cancer Prev. 4, 329-332.

Chang D, Fanwang F, Zhao YS, Pan HZ. 2008. Evaluation of Oxidative Stress in Colorectal Cancer Patients. Biomedical And Environmental Sciences 21, 286-289.

Chang WC, Chapkin RS Lupton JR. 1997. Predictive value of proliferation, differentiation and apoptosis as intermediate markers for colon tumorigenesis. Carcinogenesis 18, 721-730.

Chang WCL, Chapkin RS, Lupton JR. 1998. Fish oil blocks azoxymethaneinduced rat colon tumorigenesis by increasing cell differentiation and apoptosis rather than decreasing cell proliferation. J. Nutr. 128, 491 497.

Chapkin RS, Seo J, McMurray DN Lupton JR. 2008. Mechanisms by which docosahexaenoic acid and related fatty acids reduce colon cancer risk and inflammatory disorders of the intestine. Chem. Phys. Lip. 153, 14-23.
Cheng JL, Futakuchi M, Ogawa K, Iwata T, Kasai M, Tokudome S, Hirose M, Shirai T. 2003. Dose response study of conjugated fatty acid derived from safflower oil on mammary and colon carcinogenesis pretreated with 7,12-dimethylbenz[a]anthracene (DMBA) and 1,2-dimethylhydrazine (DMH) in female SpragueDawley rats. Cancer Lett. 196, 161-8.

Choudhary G, Hansen H. 1998. Human health perspective on environmental exposure to hydrazines, a review. Chemosphere, 37, 801-843.

DGKC: Deutsche Gesellschaft für klinische Chemie. Empfehlungen der deutschen Gesellschaft für Klinische Chemie. 1972. Recommendation of the German Society of Clinical Chemistry. Standardization of methods for measurement of enzymatic activities in biological fluids. Z Klin Chem. Klin Biochem. 10, 281-91.

Dougherty U, Cerasi D, Taylor I, Kocherginsky M, Tekin U, Badal S, Aluri L, Sehdev A, Cerda S, Mustafi R, Delgado J, Joseph L, Zhu H, Hart J, Threadgill D, Fichera A, Bissonnette M. 2009. Epidermal growth factor receptor is required for colonic tumor promotion by dietary fat in the azoxymethane/dextran sulfate sodium model: roles of transforming growth factor\{alpha\} and PTGS2. Clin. Cancer Res. 15, 6780-9.

Fisher RA. 1970. Statistical method for research workers, Edinburgh ed. 14, Oliver and Boyed PP. 140-142.

Folch J, Lees M, Sloane-Stanley GH. 1957. A simple method for the isolation and purification of total lipids from animal tissue. J. Biol. Chem. 226, 497

Fujise $T$, Iwakiri $R$, Kakimoto $T$, Shiraishi R, Sakata $Y$, Wu B, Tsunada S, Ootani A, Fujimoto K. 2007. Longterm feeding of various fat diets modulates azoxymethane-induced colon carcinogenesis through Wnt/beta-catenin signaling in rats. Am. J. Physiol. Gastrointest Liver Physiol. 292, G1150-1156.

Gallego FJ, Pérez MA, Núňez Y, Hidalgo P. 2005. Comparison of RAPDs, AFLPs and SSR markers for the genetic analysis of yeast strains of Saccharomyces cerevisiae. Food Microbiol. 22, 561-568.

Giovannucci E, Willett WC. 1994. Dietary factors and risk of colon cancer. Ann. Med. 26, 443-452.

Granados S, Quiles JL, Gil A, Ramírez-Tortosa MC. 2006. Dietary lipids and cancer. Nutr. Hosp. 21, 42-54.

Hill M, Mazal D, Biron VA, Pereira L, Ubillos L, Berriel E, Ahmed H, Freire T, Rondán M, Vasta GR, Liu FT, Iglesias MM, Osinaga E. 2010. A Novel Clinicallyrelevant Animal Model to Study Galectin-3 and Its Ligands During Colon Carcinogenesis. J. Histochem. Cytochem. 58, 553-65.

Horng YM, Chen YT, Wu CP, Jea YS, Huang MC. 2004. Cloning of Taiwan water buffalo male-specific DNA sequence for sexing. Theriogenology 62 , 1536-1543.

Jemal A, Murray T, Samuels A, Ghafoor A, Ward E, Thun MJ. 2003. Cancer Statistics, CA Cancer J. Clin. 53, 5-26.

Jordan A, and Stein J. 2001. Modulation of epidermal growth factor-induced cell proliferation by an omega-3 fatty-acid-containing lipid emulsion on human pancreatic cancer cell line Mia Paca-2. Nutrition 17, 474-475.

Jwanny EW, Moharib SA and Rasmy GE. 2009. Effect of two polysaccharides on chemically-induced colorectal cancer in rats Etidal E. Advances in Food Science 31, 202-209.

Jwanny EW, Salem AM, Moharib SA and Rasmy GE. 2001. Effect of fish oil ethyl esters on hyperlipidemic hamsters. Bull. NRC Egypt. 26, 451-565. 
Jwanny EW, Salem AM, Shanab GM and Rasmy GE. 2004. Improved Lipid Lowering Activity of Fibrates On Combination With Fish Oil Ethyl Ester In Hypertriglyceridemic Hamsters. Advances in Food Science 26, 1-10.

Kamaleeswari M, Deeptha K, Sengottuvelan M, and Nalini N. 2006. Effect of dietary caraway (Carum carvi L.) on aberrant crypt foci development, fecal steroids, and intestinal alkaline phosphatase activities in 1,2-dimethylhydrazine-induced colon carcinogenesis. Tox. Appl. Pharmacol. 214, 290-296.

Khalil WKB, Ahmed KA, Park MH, Kim YT, Park HH, Abdel-Wahhab MA. 2008. The inhibitory effects of garlic and Panax ginseng extract standardized with ginsenoside $\mathrm{Rg} 3$ on the genotoxicity, biochemical and histological changes induced by Ethylenediaminetetraacetic acid in male rats. Arch. Toxicol. 82,183-195.

Khalil WKB, Mahmoud MA, Zahran MM, Mahrous KF. 2007. A sub acute study of metronidazole toxicity assessed in Egyptian Tilapia zillii. Journal of Applied Toxicology 27, 380-390.

Kornberg LJ, Villaret D, Popp M, Lui L, McLaren R, Brown $\mathrm{H}$, et al. 2005. Gene expression profiling in squamous cell carcinoma of the oral cavity shows abnormalities in several signaling pathways. Laryngoscope 115, 690-698.

Latham P, Lund EK and Johnson IT. 1999. Dietary n-3 PUFA increases the apoptotic response to 1,2dimethylhydrazine, reduces mitosis and suppresses the induction of carcinogenesis in the rat colon. Carcinogenesis 20, 645-650.

Lee JY and Hwang DH. 2002. Docosahexaenoic acid suppresses the activity of peroxisome proliferatoractivated receptors in a colon tumor cell line. Biochem. Biophys. Res. Comm. 298, 667-674.

Lepage G. and Roy C. 1986. Direct transesterification of all classes of lipids in one-step reaction. J. Lip. Res., 27, 114-120.

Levin B, Lieberman DA, McFarland B, Smith RA, Brooks D, Andrews KS, Dash C, Giardiello FM, Glick S, Levin TR, Pickhardt P, Rex DK, Thorson A, Winawer SJ. 2008. Screening and surveillance for the early detection of colorectal cancer and adenomatous polyps, 2008: a joint guideline from the American Cancer Society, the US Multi-Society Task Force on Colorectal Cancer, and the American College of Radiology. CA Cancer J. Clin. 58, 130-60.

Levine AJ. 1997. P53, the cellular gatekeeper for growth and division. Cell 88, 323-331.

Moreira AP, Sabarense CM, Dias CM, Lunz W, Natali AJ, Glória MB, Peluzio MC. 2009. Fish oil ingestion reduces the number of aberrant crypt foci and adenoma in 1,2-dimethylhydrazine-induced colon cancer in rats. Braz. J. Med. Biol. Res. 42 , 1167-72.

Nalini N, Manju V, Menon VP. 2004. Effect of coconut cake on the bacterial enzyme activity in 1,2-dimethyl hydrazine induced colon cancer. Clin. Chim. Acta 342, 203-10.

Narayanan BA, Narayanan NK, Reddy BS. 2001. Docosahexaenoic acid regulated genes and transcription factors inducing apoptosis in human colon cancer cells. Int. J. Oncol. 19, 1255-62.

Ohkawa H, Ohishi N, Yagi K. 1979. Assay for lipid peroxides in animal tissues by thiobarbituric acid reaction. Analytical Biochemistry 95, 351-358.

Parker St, Tong T, Bolden S, Wingo P. 1995. Cancer statistics. CA Cancer J. Clin. 47, 5-27.
Pell JD, Brown JC, Johnson IT. 1994. Polyunsaturated fatty acids of the n-3 series influence intestinal crypt cell production in rats. Carcinogenesis 15, 11151119.

Rao CV, Hirose Y, Indranie C, Reddy BS. 2001. Modulation of experimental colon tumorigenesis by types and amounts of dietary fatty acids. Cancer Res. 61, 1927-33.

Reddy BS, Burill C, Rigotty J. 1991. Effect of diets high in $v-3$ and v- 6 fatty acids on initiation and postinitiation stages of colon carcinogenesis. Cancer Res. 51, 487491.

Reddy BS. 2000. Novel approaches to the prevention of colon cancer by nutritional manipulation and chemoprevention. Cancer Epidemiol. Biomarkers Prev. 9, 239-247.

Reitman S, Frankel S. 1957. A colorimetric method for the determination of serum glutamic oxaloaceytate aminotransferase. Am. J. Clin. Pathol. 28, 56-63.

Riboli E and Norat T. 2003. Epidemiologic evidence of the protective effect of fruit and vegetables on cancer risk. Am. J. Clin. Nutr. 78, 559S-569.

Rose DP, Connolly JM. 2000. Regulation of tumor angiogenesis by dietary fatty acids and eicosanoids. Nutr. Cancer 37, 119-127.

Sala-Vila A, Folkes J, Calder PC. 2010. The Effect of Three Lipid Emulsions Differing in Fatty Acid Composition on Growth, Apoptosis and Cell Cycle Arrest in the HT-29 Colorectal Cancer Cell Line. Clin. Nutr., 29, 519-2.

Sarotra P, Sharma G, Kansal S, Negi AK, Aggarwal R, Sandhir R, Agnihotri N. 2010. Chemopreventive effect of different ratios of fish oil and corn oil in experimental colon carcinogenesis. Lipids 45, 785-98.

SAS, 1982. SAS user's guide: statistics, 1982 edn. SAS Institute Inc., Cary, NC.

Sasaki M, Kato N, Watanabe H, Yamada H. 2000. Silk protein, sericin, suppresses colon carcinogenesis induced by 1,2-dimethylhydrazine in mice. Oncol. Rep. 7, 1049-52.

Seo T, Blaner WS, Deckelbaum RJ. 2005. N-3 fatty acids: molecular approaches to optimal biological outcomes. Curr. Opin. Lipidol. 16, 11-8.

Sharma A, Belna J, Logan J. et al. 2005. The effects of Omega-3 fatty acids on growth regulation of epithelial ovarian cancer cell lines. Gynecol. Oncol. 99, 58.

Skehan P, Storeng R, Scudiero D, Monks A, McMahon J, Vistica D, Warren JT, Bokesch H, Kenney S, Boyd MR. 1990. New colorimetric cytotoxicity assay for anticancer-drug screening. J. Natl. Cancer Inst. 82, 1107-12.

Stoll BA. 2002. N-3 fatty acids and lipid peroxidation in breast cancer inhibition. Br. J. Nutr. 87, 193-8.

Tavani A, Pelucchi C, Parpinel M, Negri E, Franceschi S, Levi F, La Vecchia C. 2003. $n$-3 polyunsaturated fatty acid intake and cancer risk in Italy and Switzerland. Int. J. Cancer 105, 113-116.

Thapa D, Babu D, Park MA, Kwak MK, Lee YR, Kim JM, Kwon TK, Kim JA. 2010. Induction of p53-independent apoptosis by a novel synthetic hexahydrocannabinol analog is mediated via Sp1-dependent NSAIDactivated gene-1 in colon cancer cells. Biochemical Pharmacology 80, 62-71.

van Beelen VA, Spenkelink B, Mooibroek H, Sijtsma L, Bosch D, Rietjens IMCM and Alink GM. 2009. An n-3 PUFA-rich microalgal oil diet protects to a similar extent as a fish oil-rich diet against AOM-induced colonic aberrant crypt foci in F344 rats. Food Chem. Tox., 47, 316-320. 
Ward JM. 1974. Morphogenesis of chemically induced neoplasm of the colon and small intestine in rats. $L a b$. Invest. 30, 505-513.

Watson JL, Hill R, Lee PW, Giacomantonio CA, Hoskin DW. 2008. Curcumin induces apoptosis in HCT-116 human colon cancer cells in a p21-independent manner Exp. Molec. Path. 84, 230-233.

WHO report, 2006 on WHO official website: http://www. who.int/research/en/.

Wong R. 2010. Proximal Tumors Are Associated with Greater Mortality in Colon Cancer. J. Gen. Intern. Med. 25, 1157-63.

Wu B, Iwakiri R, Ootani A, Tsunada S, Fujise T, Sakata Y, Sakata H, Toda S, Fujimoto K. 2004. Dietary corn oil promotes colon cancer by inhibiting mitochondriadependent apoptosis in azoxymethane-treated rats. Exp. Biol. Med. 229, 1017-1025.

Wynder EL, Kajitani T, Ishikawa S, Dodo H, Takano A. 1969. Environmental factors of cancer of colon and rectum. Cancer 23, 1210-1220.

Yang P, Felix E, Madden T, Chan D, Newman RA. 2002. Relative formation of PGE2 and PGE3 by eicosapentaenoic acid (EPA) and docosahexaenoic acid (DHA) in human lung cancer cells. Proc. Am. Assoc. Cancer Res. 43: number 1533 (abs.).

Recibido: 14/09/10 Aceptado: $9 / 11 / 10$ 